\title{
Analisis pemahaman konseptual mahasiswa pada materi kinematika partikel melalui tes diagnostik
}

\author{
Ino Angga Putra, Eko Sujarwanto, dan Novia Ayu Sekar Pertiwi \\ Program Studi Pendidikan Fisika Universitas KH. A. Wahab Hasbullah \\ Jalan Garuda No. 09 Tambakberas Jombang \\ Surat-e: inoanggaputra@unwaha.ac.id
}

Perkembangan pembelajaran pada saat ini terfokus pada pembelajaran student center. Peserta didik diberikan kesempatan untuk membangun pemahamannya terhadap konsep pelajaran yang diperoleh dari pendidik (sebagai fasilitator). Upaya mengatasi kesulitan dalam membangun pemahaman, mencapai ketuntasan dan mengurangi miskonsepsi peserta didik maka digunakan evaluasi pembelajaran melalui Tes Diagnostik. Tujuan penelitian ini yaitu a) mengetahui pemahaman konseptual mahasiswa dalam mengkaji konsep-konsep dasar kinematika partikel, dan b) mengetahui kesulitan pemahaman konseptual mahasiswa pada konsep dasar kinematika partikel. Jenis penelitian ini adalah Penelitian ini menggunakan model penelitian deskriptif eksploratif. Instrumen pengumpulan data menggunakan instrumen penilaian diagnostik TwoTier. Peningkatan tersebut ditunjukkan melalui hasil rata-rata skor gain yang ternormalisasi sebesar 0,02. Hasil analisis data pemahaman konsep mahasiswa menggunakan instrumen tes diagnostik menunjukkan bahwa pemahaman konsep mahasiswa meningkat sebesar $2 \%$. Hasil analisis data penelitian menunjukkan bahwa mahasiswa mengalami miskonsepsi pada konsep kinematika partikel. Hal ini dikarenakan mahasiswa masih lemah dalam menganalisis suatu permasalahan melalui bentuk representasi.

\begin{abstract}
The development of learning at this time focused on student center learning. Learners are given the opportunity to build their understanding of the lesson concept learned from the educator (as the facilitator). Efforts to overcome difficulties in building understanding, achieve mastery and reduce the misconceptions of learners then used the evaluation of learning through the Diagnostic Test. The purposes of this research are: a) to know the conceptual understanding of students in studying basic concepts of particle kinematics, and b) to know the difficulties of conceptual understanding of students on the basic concept of particle kinematics. The type of this research is research use descriptive explorative research model. The data collection instrument uses a diagnostic evaluation instrument Two-Tier. The increase was shown through the average result of a normalized gain score of 0.02. The result of data analysis of student conceptual understanding using diagnostic test instrument showed that students concept comprehension increased by $2 \%$. The results of data analysis showed that students have misconceptions on the concept of kinematics particles. This is because students are still weak in analyzing a problem through the form of representation.
\end{abstract}

Kata kunci: kinematika partikel, miskonsepsi, pemahaman konseptual, tes diagnostik

\section{Pendahuluan}

Perkembangan pembelajaran pada saat ini terfokus pada pembelajaran student center. Konsep pembelajaran ini diyakini sebagai pembelajaran yang baik untuk mendorong dan meningkatkan kinerja siswa untuk belajar dan mengoptimalkan segala kemampuan, keterampilan, dan potensi yang dimiliki. Pustaka [I] menyatakan bahwa pembelajaran student center dikembangkan melalui pendekatan konstruktivisme yang didasarkan pada kepercayaan bahwa peserta didik sudah mengerti sebagian besar dari faktor yang menentukan dalam hasil pembelajaran. Peserta didik diberikan kesempatan untuk membangun pemahamannya terhadap konsep pelajaran yang diperoleh dari pendidik (sebagai fasilitator). 
Berdasarkan kenyataan di lapangan diketahui bahwa banyaknya peserta didik yang mengalami penurunan prestasi belajarnya. Hal ini didukung beberapa data dimana peserta didik mengalami remidi pada materi Kinematika dan Dinamika Partikel. Peserta didik mengalami kesulitan dalam menguasai konsep Kinematika Partikel. Peserta didik juga banyak mengalami miskonsepsi pada materi Kinematika Partikel [2] dan [3]. Hal ini juga didukung penelitian lain tentang pemahaman konseptual kinematika oleh pustaka [4] dan [5]. Materi Kinematika dan Dinamika Partikel lebih berhubungan dengan kehidupan sehari-hari sehingga menuntut peserta didik untuk dapat menghubungkan konsep yang sudah dimiliki dengan konsep Fisika sebenarnya. Hal ini dipertegas oleh pustaka [6] dimana pemahaman mahasiswa tentang percepatan dan kecepatan masih sangat lemah meskipun telah mempelajari konsep tersebut melalui mata kuliah Fisika Dasar dan Mekanika, bahkan sejak belajar Sains di SMP. Oleh karena itu, diperlukan suatu evaluasi pembelajaran yang dapat mengurangi miskonsepsi peserta didik.

Upaya mengatasi kesulitan mencapai ketuntasan dan mengurangi miskonsepsi peserta didik maka digunakan evaluasi pembelajaran melalui Tes Diagnostik. Tes diagnostik memiliki dampak terhadap kegiatan belajar mengajar. Tes diagnostik dapat meningkatkan hasil belajar peserta didik. Tes diagnostik dapat mengatasi kesulitan belajar dan mengurangi miskonsepsi peserta didik. Tujuan tes diagnostik adalah untuk menentukan pengajaran yang perlu dilakukan pada masa yang akan datang [7]. Oleh karena itu, tes diagnostik seharusnya dirancang agar format dan responnya memiliki fungsi diagnostik. Format tes yang dapat digunakan untuk mendapatkan informasi secara lengkap diantaranya adalah dalam bentuk pilihan ganda yang dibuat berdasarkan analisis kesulitan yang dialami peserta didik.

Tes diagnostik yang digunakan adalah merupakan tes dengan dua tingkat (2-tier). Tes ini pertama kali dikembangan oleh David F. Treagust pada tahun 1988 dengan berupa soal pilihan ganda bertingkat. Tes ini digunakan sebagai cara yang efektif dan efisien untuk mengukur konsep-konsep peserta didik [8]. Tier pertama merupakan pernyataan proporsional dan bagian dari peta konsep yang dibuat dengan bentuk pilihan ganda. Tier kedua merupakan bentuk pernyataan confidence rating yang mendukung jawaban dari tier pertama. Hal ini membantu dalam menganalisis jawaban peserta didik dan pemahaman peserta didik terhadap suatu konsep. Instrumen two-tier juga pernah digunakan oleh beberapa peneliti dalam menganalisa pemahaman konseptual peserta didik [9] dan [I0]. Hal ini dipertegas oleh pustaka [II] melalui hasil penelitiannya bahwa melalui instrumen ini kemungkinan siswa untuk menebak jawaban benar dapat diperkecil menjadi $4 \%$.
Penerapan tes diagnostik memberikan pengaruh kepada peserta didik. Penilaian tes diagnostik dapat memberikan informasi mengenai tingkat pemahaman konsep peserta didik [I2], [I3], [I4], dan [I5]. Pustaka [I6] menyatakan bahwa melalui tes diagnostik dapat mengetahui konsep peserta didik berdasarkan koneksi antara pengetahuan dan peristiwa Fisika. Selain itu, pustaka [I7] menyatakan bahwa melalui instrumen tes diagnostik dapat mengetahui tingkat keterampilan proses sains selain pemahaman konsep peserta didik. Tes diagnostik juga dapat digunakan untuk mengetahui tingkat representasi peserta didik terhadap suatu konsep [I8] dan [19].Hal tersebut dipertegas oleh pustaka [20] dimana penilaian tes diagnostik membantu pendidik untuk mengetahui tingkat miskonsepsi peserta didik terhadap suatu materi.

Berdasarkan hal tersebut, maka yang dikaji dalam penelitian ini meliputi: (I) mengetahui pemahaman konseptual mahasiswa dalam mengkaji konsep-konsep dasar kinematika partikel dan (2) mengetahui hasil pemahaman konseptual mahasiswa pada konsep dasar kinematika partikel melalui tes diagnostik.

\section{Kajian Pustaka}

\section{Pemahaman konseptual}

Pemahaman konsep dapat diartikan sebagai kemampuan siswa dalam memahami makna secara ilmiah, baik secara konsep maupun teori serta penerapannya dalam kehidupan sehari-hari. Hubungan antara konsep-konsep dalam suatu materi pelajaran dapat diwujudkan dalam bentuk rumus-rumus untuk memecahkan masalah, grafik, bagan, poster, tabel, dan bentuk hubungan lain. Penguasaan konsep juga merupakan bagian dari hasil belajar pada komponen pembelajaran karena konsep, prinsip, dan struktur pengetahuan dan pemecahan masalah merupakan bagian hasil belajar pada ranah kognitif.

Berdasarkan Taksonomi Bloom, penguasaan konsep dalam penelitian ini meliputi ranah kognitif dimana ditunjukkan pada tabel I.

Tabel I. Taksonomi Bloom (Taxonomy of Educational Objectives)

\begin{tabular}{ll}
\hline $\begin{array}{l}\text { CI Mengingat } \\
\text { (Remember) }\end{array}$ & Mengenali (recognizing), Mengingat (recalling). \\
\hline $\begin{array}{l}\text { C2 Memahami } \\
\text { (Understand) }\end{array}$ & $\begin{array}{l}\text { Menafsirkan (interpreting), Membari Contoh } \\
\text { (exampliying), Meringkas (summarizing), } \\
\text { Menarik Inferensi (inferring), Membandingkan } \\
\text { (compairing), Menjelaskan (explaining). }\end{array}$ \\
\hline C3 & $\begin{array}{l}\text { Menjalankan (executing), } \\
\text { Mengaplikasikan } \\
\text { (Apply) }\end{array}$ \\
\hline $\begin{array}{l}\text { C4 Menganalisis } \\
\text { (Analyze) }\end{array}$ & $\begin{array}{l}\text { Menguraikan (differentiating), Mengorganisir } \\
\text { (organizing), Menemukan makna tersirat }\end{array}$ \\
\hline $\begin{array}{l}\text { C5 Evaluasi } \\
\text { (Evaluate) }\end{array}$ & Memeriksa (checking), mengkritik (critiquing) \\
\hline $\begin{array}{l}\text { C6 Membuat } \\
\text { (Create) }\end{array}$ & $\begin{array}{l}\text { Merumuskan (generating), Merencanakan } \\
\text { (planning), Memproduksi (producing). }\end{array}$ \\
\hline
\end{tabular}




\section{Tes Diagnostik}

Tes diagnostik merupakan tes yang digunakan untuk mengetahui kelemahan-kelemahan/kesulitan peserta didik dalam pembelajaran. Hasil tes ini digunakan sebagai dasar untuk memberikan tindak lanjut yang tepat sesuai dengan kelemahan yang dimiliki siswa [2I]. Tes diagnostik memiliki fungsi, antara lain a) menentukan apakah konsep telah dikuasai atau belum, b) menentukan tingkat penguasaan peserta didik terhadap konsep yang dipelajari, c) mengelompokkan peserta didik berdasarkan kemampuan dalam menerima pelajaran yang akan dikuasai, dan d) menentukan kesulitan-kesulitan belajar yang dialami untuk menentukan cara yang khusus dalam mengatasi atau memberikan bimbingan [22]. Hal ini dipertegas oleh pustaka [2I] dimana tes diagnostik berfungsi untuk mengidentifikasi masalah atau kesulitan yang dialami peserta didik serta merencanakan tindak lanjut berupa upaya-upaya pemecahan sesuai dengan kesulitan yang telah teridentifikasi. Dengan demikian, tes diagnostik merupakan suatu bentuk penilaian pembelajaran dalam bentuk tes yang disusun untuk mengidentifikasi atau mendiagnosis kesulitan-kesulitan peserta didik dalam memahami suatu konsep serta memberikan tindak lanjut dalam mengatasi kesulitankesulitan tersebut.

Tes diagnostik memiliki karakteristik tersendiri dibanding dengan tes ukur peserta didik yang lain. Pustaka [2I] menyebutkan karakteristik tes diagnostik antara lain: a) dirancang untuk mengidentifikasi kesulitan atau masalah belajar peserta didik, b) dikembangkan berdasarkan analisis kesulitan atau masalah belajar yang teridentifikasi, c) disertai rancangan tindak lanjut sesuai kesulitan atau masalah belajar yang teridentifikasi, dan d) menggunakan soal-soal bentuk supply respone (bentuk uraian atau jawab singkat).

Tes diagnostik memiliki dampak terhadap kegiatan belajar mengajar. Tes diagnostik dapat meningkatkan hasil belajar peserta didik. Tes diagnostik dapat mengatasi kesulitan belajar dan mengurangi miskonsepsi peserta didik. Tujuan tes diagnostik adalah untuk menentukan pengajaran yang perlu dilakukan pada masa yang akan datang [22]. Oleh karena itu, tes diagnostik seharusnya dirancang agar format dan responnya memiliki fungsi diagnostik. Format tes yang dapat digunakan untuk mendapatkan informasi secara lengkap diantaranya adalah dalam bentuk pilihan ganda yang dibuat berdasarkan analisis kesulitan yang dialami peserta didik.

\section{Metode Penelitian}

Jenis penelitian ini adalah penelitian deskriptif kuantitatif. Desain penelitian adalah penelitian survey. Populasi penelitian adalah mahasiswa Program Studi Pendidikan Fisika UNWAHA. Instrumen penilaian dalam penelitian adalah instrumen tes diagnostik pemahaman konsep two-tier. Pengumpulan data penelitian dengan cara observasi instrumen pretestposttest penguasaan konsep mahasiswa. Data penelitian yang diperoleh berupa jumlah mahasiswa yang paham konsep dan mengalami miskonsepsi pada saat pretest dan posttest. Hasil data tersebut dipersentasekan dan dilakukan analisis data dengan menggunakan uji gain ternormalisasi (n-gain) untuk mengetahui peningkatan pemahaman konsep siswa pada materi Kinematika Partikel.

Data yang dibahas pada artikel ini berasal pada hasil ujian dalam semester pada topik kinematika dan dinamika partikel. Soal ujian terdiri dari I5 soal dalam bentuk pilihan ganda. Artikel ini hanya membahas hasil ujian terhadap pertanyaan-pertanyaan yang disesuaikan pada topik penelitian yang dilakukan. Hasil ujian diperoleh dengan menggunakan instrumen two-tier diagnostic test. Mahasiswa memilih jawaban dari pertanyaan pilihan ganda dan juga diminta untuk memberikan pilihan skor atas tingkat ketepatan atau keyakinan jawaban dengan skala likert dengan skor 0 sampai 3 (Tabel I). Skor 3 menyatakan sangat yakin akan ketepatan jawabannya, sedangkan skor 0 menyatakan sangat tidak yakin atau hanya menebak saja. Skor I dan 2 menyatakan tingkat keyakinan berada diantara kedua skor ekstrim tersebut.

\section{Hasil Penelitian dan Pembahasan}

Hasil data penelitian melalui instrumen tes diagnostik pada kegiatan pretest dan posttest disajikan pada Tabel 2.

Tabel 2. Jumlah Mahasiswa dan Persentase Pemahaman Konsep Pada Tiap Butir Soal

\begin{tabular}{|c|c|c|c|c|c|c|c|c|c|c|c|c|c|c|c|c|c|}
\hline \multirow{3}{*}{$\begin{array}{l}\text { Butir } \\
\text { Soal }\end{array}$} & \multicolumn{4}{|c|}{ Paham Konsep } & \multicolumn{4}{|c|}{ Culkup Pahtam } & \multicolumn{4}{|c|}{ Lemah Konsep } & \multicolumn{4}{|c|}{ Miskonsepsi } & \multirow{3}{*}{$\begin{array}{l}\text { Peningkatan } \\
\text { Pemahaman } \\
\text { Konsep }(\%)\end{array}$} \\
\hline & \multicolumn{2}{|c|}{ Pre } & \multicolumn{2}{|c|}{ Post } & \multicolumn{2}{|c|}{ Pre } & \multicolumn{2}{|c|}{ Post } & \multicolumn{2}{|c|}{ Pre } & \multicolumn{2}{|c|}{ Post } & \multicolumn{2}{|c|}{ Pre } & \multicolumn{2}{|c|}{ Post } & \\
\hline & $\mathrm{N}$ & $\%$ & $\mathrm{~N}$ & $\%$ & $\mathrm{~N}$ & $\%$ & $\mathrm{~N}$ & $\%$ & $\mathrm{~N}$ & $\%$ & $\mathrm{~N}$ & $\%$ & $\mathrm{~N}$ & $\%$ & $\mathrm{~N}$ & $\%$ & \\
\hline 1 & 0 & 0 & 2 & 7 & 1 & 4 & 0 & 0 & 10 & 30 & 8 & 37 & 18 & 67 & 15 & 56 & $\pi$ \\
\hline 2 & 1 & 4 & 0 & 0 & 1 & 4 & 1 & 4 & 17 & 30 & 8 & 63 & 17 & 63 & 9 & 33 & \\
\hline 3 & 1 & 4 & 4 & 15 & 1 & 4 & 2 & 7 & 9 & 4 & 1 & 33 & 24 & 89 & 12 & 44 & 21 \\
\hline 4 & 7 & 26 & 7 & 26 & 0 & 0 & 7 & 21 & 13 & 59 & 16 & 38 & 4 & 15 & 7 & 26 & 37 \\
\hline 5 & 0 & 0 & 0 & 0 & 0 & 0 & 0 & 0 & 16 & 37 & 10 & 59 & 17 & 63 & 11 & & 0 \\
\hline 6 & 3 & 11 & 4 & 15 & 4 & 14 & 1 & 4 & 19 & 67 & 18 & 70 & 2 & 7 & 3 & & 12 \\
\hline 7 & 3 & 11 & 2 & 7 & 7 & 26 & 3 & 11 & 15 & 56 & 15 & 56 & 2 & 7 & 7 & & 36 \\
\hline 8 & 3 & 4 & 1 & 4 & 0 & 0 & 0 & 0 & 20 & 74 & 20 & 74 & 6 & 22 & 6 & 22 & 0 \\
\hline
\end{tabular}

\section{Pemahaman mahasiswa tentang konsep percepatan}

Pemahaman mahasiswa tentang konsep percepatan disajikan pada bentuk butir soal (Gambar 2). Tingkat pemahaman mahasiswa terhadap distribusi jawaban disajikan pada Tabel 2 dengan fokus pada hasil posttest karena pada pretest masih berupa kemampuan awal mahasiswa. Butir sel tersebut memiliki jawaban tepat atas pertanyaan adalah D. Berdasarkan data tersebut, pemahaman mahasiswa sangat baik sebesar 7\% mahasiswa. Pemahaman mahasiswa dalam kategori cukup 
sebesar 0\% dan dalam kategori lemah sebesar 37\%. Mahasiswa mengalami miskonsepsi sebesar 56\%.

Jawaban benar pada pertanyaan tersebut, mahasiswa dituntut mampu: I) menerapkan pengetahuan mereka tentang definisi percepatan dan 2) mengaktivasi pengetahuan tentang bentuk representasi dari konsep percepatan. Pada tabel 2 menunjukkan bahwa mahasiswa yang memilih jawaban benar dan yang yakin atas ketepatan atau keyakinan jawabannya sebesar 7\%.

Mahasiswa memilih jawaban E berarti mereka tidak menggunakan konsep pengetahuan prasyarat tersebut. Ada beberapa hal yang menjadi kemungkinan penyebab hal tersebut [3] yaitu: I) mereka memang mengetahui akan soal tersebut, tetapi mereka gagal dalam menerapkan pengetahuannya tentang definisi percepatan, dan 2) mereka memang mampu dalam mengaktivasi pengetahuan tentang konsep percepatan, namun belum bisa dalam mengaktivasi bentuk representasinya.

Mahasiswa yang memilih jawaban A, B, dan C telah berhasil dalam mengaktivasi pengetahuan tentang konsep percepatan namun belum berhasil dalam merepresentasikan bentuk umumnya. Khusus jawaban C, mereka mampu menerapkan pengetahuan dan mengaktivasi pengetahuan melalui representasi tetapi tidak teliti dalam menentukan hasil yang didapat. Dugaan yang muncul atas jawaban tersebut adalah mahasiswa salah dalam memahami konsep percepatan. Hal ini ditunjukkan pada Tabel 2 dimana sebagian besar mahasiswa merasa yakin akan ketepatan jawabannya sehingga mahasiswa mengalami miskonsepsi sebesar 56\%.

Posisi balok "a" dan "b" pada setiap waktu yang beruutan dinyatakan pada gambar berikut. Kedua balok sedang bergeralk
kekanan.
Manakah pernyataan berikut yang benar tentang percepatan kedua balok tersebut?
(A) Percepatan balok "a" lebih besar dari pada percepatan balok "b".
(B) Percepatan balok "a" lebih kecil dari pada percepatan balok" "b".
(C) Percepatan kedua balok sama besar, lebili dari nol.
(D) Percepatan kecua balok adalah nol
(E) Tidak cukup informasi untuk menjawab pertanyaan tersebut

Gambar 2. Butir soal pemahaman konseptual mahasiswa tentang representasi konsep percepatan

\section{Pemahaman mahasiswa tentang konsep gerak lurus berubah beraturan (gerak vertikal ke atas dan gerak vertikal ke bawah)}

Pemahaman mahasiswa tentang konsep gerak lurus berubah beraturan (gerak vertikal ke atas dan gerak vertikal ke bawah) disajikan pada Gambar 3. Distribusi jawaban mahasiswa beserta tingkat jawabannya disajikan pada Tabel 2. Pada Gambar 3, jawaban yang tepat untuk butir soal tersebut adalah D. Berdasarkan data tersebut tampak bahwa hanya I5\% pemahaman mahasiswa sangat baik tentang konsep gerak lurus berubah beraturan.
Pemahaman mahasiswa dalam kategori cukup sebesar 7\%, dalam kategori lemah sebesar 33\%, dan dalam kategori miskonsepsi sebesar 44\%.

Mahasiswa menjawab benar dari pertanyaan tersebut apabila mampu: I) mengaktivasi pengetahuan tentang gerak lurus berubah beraturan yaitu konsep gerak vertikal ke atas dan gerak vertikal ke bawah, 2) menerapkan pengetahuan tentang konsep kecepatan dan percepatan dalam gerak vertikal ke atas dan ke bawah melalui tanda $(+)$ menyatakan ke atas dan tanda (-) menyatakan ke bawah, dan 3) mengaktivasi pengetahuan tentang konsep percepatan dalam gerak vertikal adalah konstan melalui bentuk representasi.

Mahasiswa memilih jawaban A dan C berarti mereka tidak menggunakan pengetahuan prasyarat tersebut. Ada beberapa hal yang menjadi kemungkinan penyebab hal tersebut yaitu: I) mereka memang mengetahui akan soal tersebut, tetapi mereka gagal dalam menerapkan pengetahuannya tentang konsep gerak lurus berubah beraturan meliputi gerak vertikal ke atas dan ke bawah, 2) mereka memang mampu dalam mengaktivasi pengetahuan tentang konsep kecepatan, namun belum bisa menentukan tanda ( + ) dan tanda (-), dan 3) mereka mampu mengaktivasi pengetahuan tentang percepatan, namun salah dalam menerapkan konsep melalui bentuk representasi.

Mahasiswa yang memilih jawaban B dan E sudah berhasil dalam mengaktivasi pengetahuan mengenai konsep gerak vertikal ke atas dan gerak vertikal ke bawah, namun belum berhasil dalam menentukan tanda $(+)$ dan tanda (-) pada konsep kecepatan (khususnya jawaban B). Khusus jawaban E, mereka mampu mengaktivasi pengetahuan dengan menentukan tanda $(+)$ dan tanda $(-)$ tetapi tidak teliti dalam menentukan atau menerapkan pengetahuan berdasarkan bentuk representasi. Kemungkinan yang terjadi adalah mahasiswa terlalu dalam memahami konsep kecepatan dan percepatan melalui penentuan tanda $(+)$ dan $(-)$. Hal ini ditunjukkan pada Tabel 2 dimana sebagian besar mahasiswa merasa yakin akan ketepatan jawabannya sehingga mahasiswa mengalami miskonsepsi sebesar 44\%.

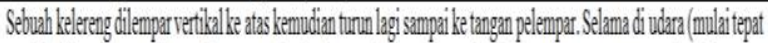

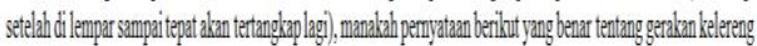 tersebut? \\ (A) Percepatannya sebanding dengan keceppatannya \\ (B) Arah heccepatanny atidak pemah sama dengan arah percepatannya \\ (C) Percepatan dean kecepatannyanol ketka di titik tetringegi \\ (D) Ketilka naik, percepatanny a berlarananan arah dengan kecepatannya \\ (E) Ketika nalk, percepatannyanegatif, tetapi meniadi positif ketilia turun \\ Gambar 3. Butir soal pemahaman konseptual mahasiswa tentang representasi konsep gerak lurus berubah beraturan (gerak vertikal ke atas dan gerak vertikal ke bawah)}




\section{Pemahaman mahasiswa tentang konsep gerak jatuh bebas}

Pertanyaan untuk mengungkap pemahaman mahasiswa tentang gerak jatuh bebas disajikan pada Gambar 4 . Tingkat pemahaman mahasiswa terhadap distribusi jawaban disajikan pada Tabel 2. Butir sel tersebut memiliki jawaban tepat atas pertanyaan adalah B. Berdasarkan data tersebut, pemahaman mahasiswa sangat baik sebesar $0 \%$ mahasiswa. Pemahaman mahasiswa dalam kategori cukup sebesar $0 \%$ dan dalam kategori lemah sebesar 59\%. Mahasiswa mengalami miskonsepsi sebesar $41 \%$.

Jawaban benar pada pertanyaan tersebut, mahasiswa dituntut mampu: I) mengaktivasi pengetahuan tentang gerak jatuh bebas terkait dengan kecepatan dan percepatan dan 2) mengaktivasi pengetahuan tentang gerak jatuh bebas melalui bentuk umum representasi berupa gambar/grafik. Berdasarkan hasil jawaban mahasiswa pada Tabel 2 menunjukkan bahwa mahasiswa yang memilih jawaban benar dan yang yakin atas ketepatan atau keyakinan jawabannya sebesar $0 \%$.

Mahasiswa memilih jawaban D berarti mereka tidak menggunakan konsep pengetahuan prasyarat tersebut. Ada beberapa hal yang menjadi kemungkinan penyebabnya yaitu: I) mereka memang mengetahui akan soal tersebut, tetapi mereka gagal dalam mengaktivasi pengetahuannya tentang bentuk umum representasi konsep gerak jatuh bebas terkait hubungan kecepatan dan waktu, dan 2) mereka memang mampu dalam mengaktivasi pengetahuan tentang konsep percepatan, namun belum bisa dalam menerapkannya ke dalam konsep. Hal ini yang menyebabkan mereka menjadi ragu terhadap jawaban yang dipilih.

Mahasiswa yang memilih jawaban A, dan E dapat dinyatakan bawah telah berhasil dalam mengaktivasi pengetahuan tentang bentuk umum representasinya namun belum berhasil dalam menerapkannya berdasarkan konsep. Mahasiswa yang memilih jawaban $\mathrm{C}$ berarti telah berhasil dalam mengaktivasi pengetahuan dan juga penerapannya tetapi tidak teliti dalam menentukan tanda $(+)$ dan tanda (-) untuk konsep kecepatan. Seperti terlihat pada Tabel 2, sebagian besar mahasiswa yang memilih A, C, dan E merasa yakin akan ketepatan jawabannya dengan kategori lemah sebesar 59\% dan kategori miskonsepsi sebesar 4I\%.

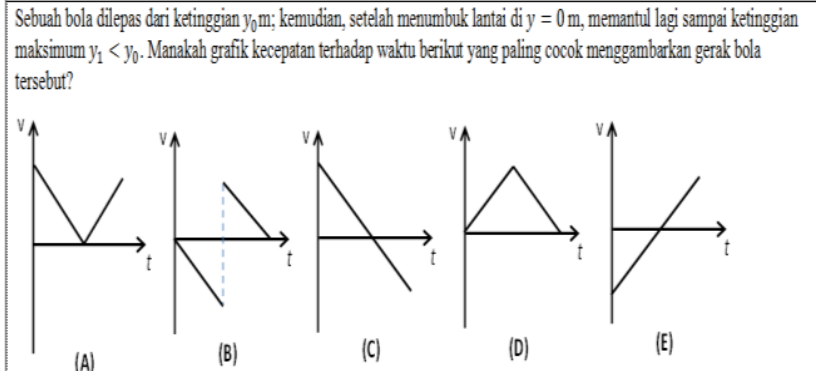

(A)

(B)

(c)

(D)

Gambar 4. Butir soal pemahaman konseptual mahasiswa tentang representasi konsep gerak jatuh bebas

Berdasarkan hasil pemahaman konseptual mahasiswa pada Tabel 2, tampak bahwa terjadi peningkatan pemahaman konseptual mahasiswa saat melakukan pretest dan posttest. Peningkatan pemahaman ditunjukkan dengan n-gain skor sebesar 0,02 atau dalam kategori nilai rendah. Hasil ini menunjukkan bahwa peningkatan pemahaman konseptual sebesar 2\%. Kemungkinan penyebab terjadinya peningkatan pemahaman konseptual mahasiswa yaitu I) minat dan perhatian mahasiswa saat proses pembelajaran berlangsung, 2) kesiapan mahasiswa dalam menerima konsep baru, 3) strategi belajar yang menarik mahasiswa, 4) penanaman konsep yang mendalam, dan 5) pemberian latihan soal-soal yang bervariasi dan cara penyelesaian oleh mahasiswa [23].

\section{Kesimpulan}

Berdasarkan penjelasan dan pembahasan sebagaimana diuraikan di depan, dapat disimpulkan bahwa konsepkonsep terkait fenomena kinematika partikel, meliputi representasi tentang kecepatan, percepatan, gerak vertikal ke atas dan ke bawah, dan gerak jatuh bebas terkait hubungan kecepatan dan waktu merupakan konsepkonsep yang sulit dipahami oleh mahasiswa. Sebagian besar mahasiswa masih mengalami kesulitan dalam menganalisa dan memecahkan persoalan berdasarkan konsep tersebut dan merepresentasikan suatu bentuk umum berupa gambar/grafik/tabel, walaupun mahasiswa sudah mempelajari konsep-konsep tersebut sejak dibangku sekolah menengah.

Beberapa hal yang menjadi penyebab kesulitan mahasiswa dalam memahami dan memecahkan permasalahan konseptual seperti halnya pada penelitian ini. Pertama, mereka mengalami miskonsepsi diartikan bahwa mereka salah dalam memahami suatu konsep namun merasa yakin benar akan konsepsinya (yang salah). Kedua, mereka yang mengalami lemah paham dapat diartikan bahwa mereka telah paham akan konsep yang dimilikinya, namun mereka gagal dalam mengaktivasi dan menerapkan pengetahuannya dalam memecahkan persoalan yang ada. Ketiga, mahasiswa mengalami cukup paham dapat diartikan bahwa mereka belum berhasil dalam menggunakan pengetahuannya untuk membuat 
kesimpulan/jawaban yang tepat sebagai solusi permasalahan, walaupun telah berhasil dalam mengaktivasi pengetahuan yang sesuai dengan permasalahan yang ada. Keempat, mereka tidak memiliki pengetahuan sains yang baik sehingga hanya mengandalkan intuisi naifnya atau hanya menebak saja [3]. Selain itu, mahasiswa mengaktivasi sumber-sumber pengetahuan (resource) yang salah karena dipengaruhi oleh common sense dimana tidak sesuai dengan kebenaran ilmiahnya [24].

Penelitian ini lebih fokus pada analisis pemahaman konseptual mahasiswa dalam memecahkan permasalahan konsep kinematika partikel berdasarkan tingkat keyakinan mahasiswa terhadap kebenaran jawabannya. Hal ini kemudian dikombinasikan dengan pilihan pengecoh agar mahasiswa dapat berpikir secara kritis dalam menentukan jawabannya. Meskipun diagnosis pemahaman konsep menggunakan instrumen two-tier, namun perlu dikaji lagi untuk menganalisis pemahaman konseptual mahasiswa secara mendalam untuk menuju High Order Thinking Skill (HOTS). Selain itu, pemahaman konseptual mahasiswa pada materi kinematika dapat ditingkatkan melalui pemberian bantuan berupa diagram gerak (representasi) [3]. Oleh karena itu, perlu dilakukan penelitian lebih lanjut dan mendalam terkait penyebab kesulitan dalam pemahaman konsep tersebut melalui instrumen three-tier atau four-tier.

\section{Ucapan Terimakasih}

Ucapan terimakasih ditujukan kepada Allah swt yang memberikan rahmat serta hidayahnya sehingga penelitian ini dapat terselesaikan tepat waktu. Ucapan terimakasih juga disampaikan kepada Lembaga Penelitian dan Pengabdian pada Masyarakat Universitas KH. A. Wahab Hasbullah yang telah turut serta dalam keterlaksanaan kegiatan penelitian ini. Ucapan terimakasih disampaikan kepada semua pihak yang sudah mendukung pelaksanaan penelitian.

\section{Kepustakaan}

[I] Chandrasegarana. A. L., Treagust, D.F., \& Mocerino, M., The Development of a Two-Tier Multiple Choice Diagnostic Instrument for Ability to Describe and Multiple Levels of Representation, Chemistry Education Research and Practice, Vol. 8, No. 3, 2007.

[2] Rosenblatt, R. \& Heckler, A. F., Systematic study of student understandaing of the relationships between the directions of force, velocity, and acceleration in one dimension, Physics Review St. Physics Education Research, Vol. 7, 201 I, 020112.

[3] Sutopo, Pembelajaran Kinematika Berbasis Diagram Gerak: Cara Baru Dalam Pengajaran Kinematika. Prosiding Smeinar Nasional Penelitian, Pendidikan, dan Penerapan MIPA, Fakultas MIPA, Universitas Negeri Yogyakarta, 2 Juni 2012.

[4] Hake, R.R., Interactive-engagement versus traditional methods: A six-thousand-student survey of mechanics test data for introductory physics courses, American Journal Physics, Vol. 66, No. 0I, I998, 64-74.
[5] Reif, F. \& Allen, S., Cognition for interpreting scientific concepts: A study acceleration, Cognition and Instruction, Vol. 9, No. I, I992, I-44.

[6] Sutopo, Liliasari, Waldrip, B., \& Rusdiana, D., The Prospective physics teachers' prior knowledge of acceleration and the alternative teaching strategy for better learning outcome. Dipublikasikan pada Seminar Nasional Pendidikan Sains, Unesa Surabaya, Desember I0 20II.

[7] Suwarto, Pengembangan Tes Diagnostik dalam Pembelajaran, Yogyakarta: Pustaka Pelajar, 2013.

[8] Treagust, D. F., Development and Use of Diagnostic Test to Evaluate Students Misconceptions in Science, Journal Science Education IO, I988.

[9] Chang, H., Chen, J., Guo, C., Chen, C., Chang, C., Lin, S., Su, W., Lain, K., Hsu, S., Lin, J., Chen, C., Cheng, Y., Wang, L., \& Tseng, Y., Investigating primary and secondary students' learning of physics concepts in Taiwan, International Journal of Science Education. Vol. 29, No.4, 2007, 465-482.

[10] Potgieter, M., Malatie, E., Gaigher, E., \& venter, E., Confidence versus performance as an indicator of the presence of alternative conceptions and inadequate problem-solving skills in Mechanics, International Journal of Science Education, Vol. 32, No. II, 2010, I407-I429.

[II] Tuysuz, C., Development of Two-Tier Diagnostic Instrument and Assess Studentd Misunderstandaing in Chemistry, Scientific Research and Essay 4, 2009.

[12] Bunawan, W., Setiawan, A., Rusli, A., \& Nahadi, Pengembangan Instrumen Tes Diagnostik Pilihan Ganda Tiga Tingkat untuk Mengakses Kemampuan Mahasiswa Calon Guru Fisika, Edusains, Vol. VI, No. 2, 2014.

[13] Marsita, R.A, Priatmoko, S., \& Kusuma, E., Analisis Kesulitan belajar Kimia Siswa SMA dalam Memahami Materi Larutan Penyangga dengan Menggunakan Two-Tier Multiple Choice Diagnostic Instrument, Jurnal Inovasi Pendidikan Kimia, Vol. 4, No. I, 20I0.

[14] Ismail, I. I., Samsudin, A., Suhendi, E., \& Kaniawati, I., Diagnostik Miskonsepsi Melalui Listrik Dinamis Four Tier Test. Prosiding Simposium Nasional Inovasi dan Pembelajaran Sains, Bandung, 8-9 Juni 2015,.

[15] Siswaningsih, W., Firman, H., Zackiyah, \& Khoirunnisa, A., Development of Two-Tier Diagnostic Test Pictorial-Based for Identifying High School Students Misconceptions on the Mole Concept. IOP Conf. Series: Journal of Physics, 2017.

[16] Winarti, Cari, Suparmi, Sunarto, W., \& Istiyono, E., Development of Two Tier Test to Assess Conceptual Understanding in Heat and Temperature, IOP Conf. Series: Journal of Physics, 2017.

[17] Wulandari, R. R. A., Yamtinah, S. \& Saputro, S., Instrumen Two-Tier Test Aspek Pengetahuan untuk Mengukur Keterampilan Proses Sains (KPS) Pada Pembelajaran Kimia untuk Siswa SMA/MA Kelas XI, Jurnal Pendidikan Kimia, Vol. 4, No. 4, 2015.

[18] Sutopo, Pemahaman Mahasiswa Tentang Konsep-Konsep Dasar Gelombang Mekanik, Jurnal Pendidikan Fisika Indonesia, Vol. I2, No. I, 2016.

[19] Wisudawati, A. W., Pengembangan Instrumen Three-Tier Test untuk Mengidentifikasi Representasi Tingkat Mikroskop Perubahan Wujud Air Sebagai Alternatif Assesment Integrasi Islam-Sains (A Preliminary Study), Seminar Nasional Kimia dan Pendidikan Kimia VII, I8 April 2015.

[20] Septiana, D., Zulfiani, Noor, M. F., Identifikasi Miskonsepsi Siswa Pada Konsep Archaebacteria Dan Eubacteria Menggunakan Two-Tier Multiple Choice, Edusains, Vol. VI, No. 2, 2014.

[2I] Tim Departemen Pendidikan Nasional, Tes Diagnostik, Jakarta: Departemen Pendidikan Nasional, 2007.

[22] Arikunto, S., Dasar-Dasar Evaluasi Pendidikan Edisi Revisi Jakarta: Bumi Aksara, 2008. 
Analisis pemahaman konseptual mahasiswa pada materi kinematika partikel melalui tes diagnostik

[23] Ana, M., R, Priatmoko, S., \& Kusuma, E., Analisis kesulitan belajar kimia siswa SMA dalam memahami materi larutan penyangga dengan menggunakan two-tier multiple choice diagnostic instrument, Jurnal Inovasi Pendidikan Kimia, Vol. 4, No. I, 2010, 5I2-520.

[24] Sujarwanto, E. \& Putra, I.A., Identifikasi Konsepsi Mahasiswa tentang Gerak melalui Penggunaan Hukum Newton, Prosiding Seminar Nasional Pendidikan IPA: Pascasarjana UM Malang, 2017. 